\title{
Tributes to Allen McDaniels, MD 1942-2019
}

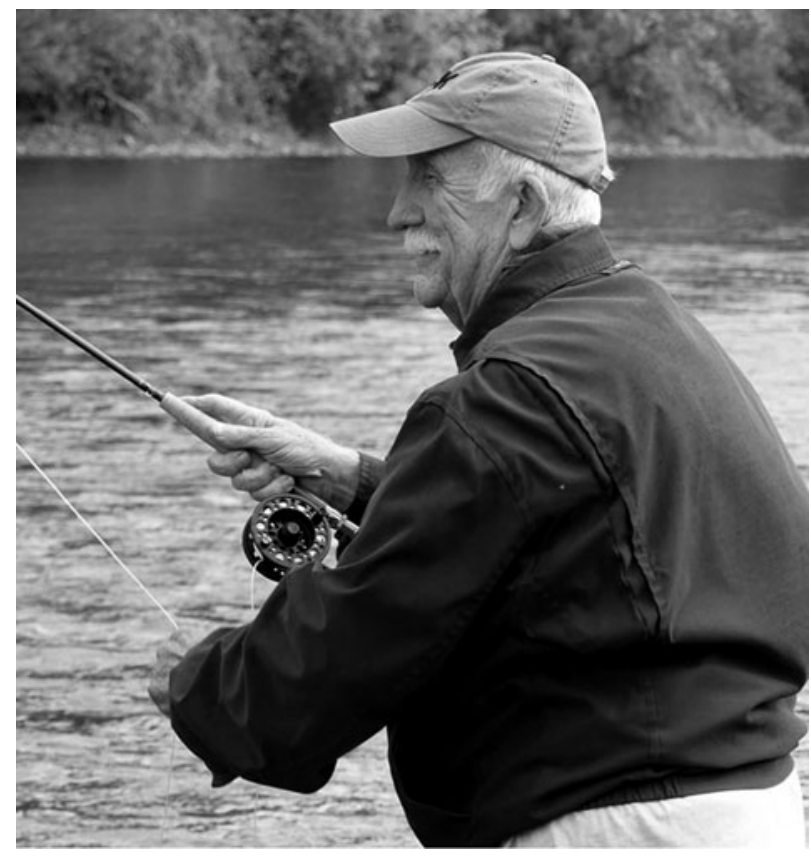

"Fishing was a form of meditation for Allen." — Maya Myslenski, MD, DABMA

From: Joseph M. Helms, MD

Helms Medical Institute Founding President

American Academy of Medical Acupuncture

met Allen McDaniels, MD, on the first day of the first University of California-Los Angeles (UCLA)-sponsored Medical Acupuncture for Physicians course. He was sitting in the front row. This was 1982. Although it was the first time I had taught at UCLA, I had prepared and delivered medical acupuncture training twice before as a core curriculum course for the American Holistic Medicine Association.

In those days, the program involved 3 10-day live sessions, and there was not yet acupuncture reading material available in English. I organized notes from my training in France and interpreted them while lecturing. There were 25 dedicated physicians in the class, and they all appeared to remain attentive while writing their own notes.

Dear front-row-Allen was the most fastidious note-taker in the class. And his handwriting was legible. Realizing a major opportunity to refine the course, I asked Allen if I might make use of his notes to help future classes manage the complex material. He loaned them to me for the fee of a case of French champagne, which I thought was very generous.

He was a natural acupuncturist, absorbing concepts and details as his birthright. His qualities of precision and generosity marked our long collaboration and friendship. We handed out the first typed version of his notes at the next class, and he joined me in precepting clinical training at the UCLA pain clinic.

For the following 37 years, Allen was a constant companion at UCLA then at Stanford then Helms Medical Institute (HMI) acupuncture training courses. He was involved in the ongoing refinement of our teaching method and material, and only rarely was unable to be first in line to volunteer his teaching talents at new courses.

Allen was good-humored and kind, widely read on subjects ranging from ornithology to big band dance music, and had a rapid retort when teased by his HMI friends, which was frequently. What was most admirably and comforting is that Allen was the only preceptor upon whom I could rely to 
give an articulate, accurate, and comprehensive lecture on any of the many topics that make up medical acupuncture training; he did this on short notice, with or without slides.

Allen was a corner post in the evolution of our medical acupuncture training and, for 2 decades, a conscientious board member of the American Medical Acupuncture Association. Our progress of introducing medical acupuncture into American medicine would not have been as refined, smooth, and successful had he not been in the front row at that first UCLA class.

We all thank you, Allen.

From: John C. Reed, MD, MDiv, FAAMA, FCA American Academy of Medical Acupuncture

I

T WAS THE SPRING OF 1988 IN BeIJING, ChINA. A group of

$20+$ physician-acupuncturists and their spouses from the year-old American Academy of Medical Acupuncture were touring the grounds of the Temple of Heaven during a 3 -week study tour of China. Our teacher/mentor Maurice Mussat had related that, after ritual preparation, the Ming Emperors had used the sacred Temple space to receive insights on the future of the realm and on the Emperor's mandate for governance. As I climbed the stairs and entered the temple, a strange feeling came over me. I looked around and saw Joe Helms and Allen McDaniels arranged in a triangle formation with me under the central roof of the temple. I felt as if the 3 of us were in a bubble of sorts, separate from the bustle of tourists and colleagues surrounding us. It felt personal and important at the time. While I never shared this with Allen or Joe, I now look back on that moment as when an unspoken message/mandate was being sent to the 3 of us. Allen's life as a physician-acupuncturist was representative of taking up that mandate and living that message.

I connect that moment directly to an earlier one that we 3 experienced on a Southern California freeway in the winter of 1986-1987. Allen, Joe, and I had navigated the freeways in Joe's Big Pink Suburban van to Orange County, where expatriate Vietnamese had settled and where we met with a leader of an association of Vietnamese-American physician acupuncturists. We thought that joining and expanding an existing clinically oriented physician association could further our dream of having a national organization that could support the integration of acupuncture into American medicine. It had been politely suggested to us that this was not a change that the current Orange County physicianacupuncturist association members would support.

At that point, Joe had been teaching his French Energeticsstyle medical acupuncture through classes sponsored by the American Holistic Medical Association and the University of California (UCLA) Extension since 1980. I had been in his second class of 7 physicians and Allen had been in his third class of 25. We had engaged for 5 years in an informal movement of physicians learning the intricacies of acupuncture practice. Sometime during the drive back to Santa Monica, CA, that afternoon, a certain fact became clear to the 3 of us. If we really wanted an organization to serve the professional practices of our newly minted physicianacupuncturist colleagues, we were the ones called upon to create it. In that moment, which hit me "in the gut," the dream of growing medical acupuncture converted from a pleasant intellectual discussion topic to being on a personal mission that spoke to each of the 3 of us in our own ways.

When we got out of the car, we embarked on that mission, and recruited our spouses to support us: My wife, Carla, was on the facilitation team for the American Academy of Medical Acupuncture's (AAMA) founding meeting on April 24,1987, Joe's wife, Pamela, was the videographer for memorializing the teachings of Dr. Mussat on the AAMA 1988 China trip, and Allen's wife, Phyllis, joined him in creating and selling AAMA sweatshirts at our first series of Annual Symposia in Philadelphia, PA, in 1989-1991. We gathered physicians with Five Element and Traditional Chinese Medicine acupuncture styles to join our UCLA course graduates at the founding meeting, where the 28 founding members elected Joe as President, me as Vice President, and Allen as Secretary/Treasurer.

Over the years, Allen provided consistent, solid, and capable support on the AAMA Board of Directors when we needed to expand, create, or confirm new programs and operational capacities. When something needed to be done to further "the dream," he would volunteer to get it done. When it came time to hire an executive director and establish an official Academy office in 1990, Allen personally conducted candidate interviews and insisted we interview an organization whose principals were 2 women, whom we did hire. That group soon merged with Jim Dowden's association management company, which has served the Academy continuously since then.

After his stint as AAMA Secretary, Allen was President of the American Foundation of Medical Acupuncture. When we needed a policy article on clean-needle techniques, Allen researched and published our definitive policy. When we needed to jump through the hoops of the Accreditation Council for Continuing Medical Education (ACCME) so that the AAMA could grant Continuing Medical Education (CME) credits, Allen became the Chair of the CME committee and made sure that happened. He spent months during 1999-2000 in biweekly commutes from San Pedro, CA, to the Wilshire, CA, AAMA office to work through this CME project (and attended a national ACCME meeting, where a cruise ship crashed into his New Orleans hotel!). He did his Academy work while being a regular faculty preceptor in the Medical Acupuncture for Physicians program for 35 years. Allen was the thoughtful, helpful, and conciliatory voice in the inevitable political squabbles of a growing organization. Typical of his deeper thinking about life and vocation, he directed our attention to the broader historical and cultural importance of the scientific tradition and medical acupuncture in his invited 1993 AAMA symposium lecture.

Allen had initially pursued a career based on mathematics and engineering in college, but was attracted to medicine as 
a more overt and personal way to be of service to others. He matriculated into medical school after doing a National Institutes of Health Fellowship. He did postdoctoral work in the humanities and completed a psychiatry and neurology residency. When starting a private practice in 1979, he also founded a tissue bank, which he directed until 1995. Seeking something beyond the often rote protocols of medical care in 1981, he quickly grasped acupuncture as a systematic form of applied health science. Acupuncture and East Asian medicine was a blend of philosophy, science, and practice that resonated with his vocational dream. He signed on to a path to fulfill that dream in 1987—a path that would transform him from student to teacher, leader, and mentor; a path that made the AAMA a part of his life. I now believe our visit to the Temple of Heaven in 1988 was a symbolic and transcendent reinforcement of his decision to embark upon a collective journey with his medical acupuncture colleagues to fulfill his vocational dream. Allen was to continue to build on that dream in the years to come.

Allen was extraordinarily capable of manifesting and sustaining the spirit of that dream in practice, teaching, and organizational politics over his many years of engagement. When others experienced burnout or ego clashes, Allen's gentle humor, quiet persistence, admirable competence, and grounded self-confidence was there to guide, support, and redirect the Academy's leaders on a sustainable path. We honor him for leaving us with the example of a life of practice, teaching, and organizational leadership that showed us how to catch a dream, form a practical vision, and build a living legacy. We have debt of profound gratitude to him for his contributions to the life of the AAMA.

Thank you, Allen!

From: Douglass N. Powell, MD, FAAMA, FACOG Helms Medical Institute Preceptor, Acus Preceptor Retired private practice of obstetrics/gynecology for 35 years Private practice of medical acupuncture and hypnosis

A Llen McDaniels was a thoughtful, passionate man; a consummate teacher; and a dear friend who never ran out of the energy to try to help me or his students. I worked with him for more than a decade as a fellow preceptor with the Helms Medical Institute (HMI).

"Well, you know, Doug," Allen started. I knew I was in for a surprising discussion on any of a wide range of topics including acupuncture: "Every president of the U.S. makes his predecessor look good. Look back in recent history. Just when we couldn't imagine a worse president, we vote one into office. I just read that in an article, and I think it's true." He had finished his journaling for the day, in pencil, in a bound leather book that he added to every morning. Allen mentioned that this had been his lifelong habit and that he had a full shelf of these books completed. He carried his mechanical pencils in a purple, leather spring-loaded case bearing his initials. He snapped it closed with a finality, emphasizing his convictions.
I hoped his premise was wrong for the upcoming election, but I enjoyed this intellectual diatribe.

"Well, you know Doug," he had started on many occasions. I knew I was in for a conversation that was well-worth considering. About 2 years ago, he gave me the clue to treating one of my favorite patients. He offered that he frequently (or always) did electroacupuncture with Chinese Scalp Acupuncture. Thereafter, I met and successfully, with Allen's suggestions, treated a poststroke patient with a 10-year history of subsequent expressive aphasia; the patient had striking and gratifying improvement. His wife, who was present at that initial treatment, and I, had tears in our eyes as he read a full paragraph to us from a random book I had picked up off my office coffee table to test the effects of the treatment. Now, he can go out to lunch with his buddies, order lunch at a café, and tell his wife that he adores her. Had Allen not told me about his own thoughts and experiences, I am confident I would have failed this patient's treatment miserably.

"Well, you know Doug...," Allen would remind me of exactly what I should have remembered to think of first, as we discussed cases. This occurred more times than I would like to admit, so I'll quit here.

My wife, Cathy, who shared many breakfasts with Allen before our long teaching seminars, remarked that he told her that a good breakfast helped put Zing in his step for the day. "Well, you know, Cathy, it's the most important meal of the day..." Zing is not how any of us might have described Allen's pace. He was methodical, organized, calm, and even-tempered, and his blue eyes belied a kind and comical nature that looked on life from a cosmic distance.

Allen's actions spoke even louder and more emphatically than his words. He experienced personal tragedy but soldiered through with the illness and passing of his wife. I noticed the subsequent hugs he gave all his colleagues were softer, longer, and more meaningful as we all gathered for teachings. He showed us his strength and softness with his continued work and acceptance of his changed status. He wrote an article in our Journal describing his thought process and treatments to help his wife get out of the intensive care unit to share time with him at home. He told me that the subsequent few months were a precious time for them both.

Allen's lifelong practice of medical acupuncture started out when acupuncture was not only unpopular, but was considered heresy and voodoo to most Western-trained physicians. He persevered, knowing acupuncture could offer so much more to his patients. It is said that if you teach a teacher, you affect all of that person's subsequent students and patients. Allen has touched not only 5000 students through the HMI and Acus Foundations, but all of their patients as well. His encyclopedic collection of facts became the little dots in a Seurat painting, creating the collage of healing that he brought with him to all his teachings- the factual items becoming more into the mix and interplay of colors until, for Allen, it became possible to be a healer. "Well, you know, Doug, that's what healing is. When all the points speak to each other and the balance of the sum is 
greater than the points themselves," he would say thoughtfully when my youthful intoxication with points and patterns threatened to obscure the "forests."

With kindness, I will remember Allen fondly as my teacher, colleague, friend, and healer.

\section{From: Bradley T. Lawrence, MD}

Medical Acupuncture, Phoenix Veterans Administration Hospital Fellow, Integrative Medicine

American Board of Family Medicine

American Board of Medical Acupuncture

American Academy of Family Practice

American Academy of Medical Acupuncture

"A man's friendships are one of the best measures of his worth." -Charles Darwin

$\mathbf{I}$ SUSPECT I SPEAK FOR MANY OF US who knew and loved Allen when I say that he was truly a dear friend and a treasured colleague. It should not have been, but it was, only in the succeeding days and weeks following his passing that I came to a full realization of this simple sentiment, I think because his memory bubbles up in so many of the situations in which I commonly find myself in both my personal and professional life.

Many things made Allen as the endearing person that he was: his sense of humor; his ability to laugh at himself; his concern for others; his love of nature and history; his adventurous spirit; his prodigious note-taking with his mechanical pencil; his propensity to suddenly produce an altimeter and announce to the group its current altitude; his always being there for us; his excellence as a physician and medical acupuncturist; and, of course, his teaching and mentoring, to name but a few things.

Allen was a lifelong student. I'm tempted to suggest that he was a polymath. I think this was driven by an insatiable curiosity. In addition to medicine, science, nature, and history, he had a strong interest in art and architecture. Whenever he would visit a new city he would look forward to visiting the local art museum and taking an architectural tour of that city. Allen was a gardener and an environmentalist. He planted trees in burn areas of California and could tell you how many of those trees survived year to year.

As I finish composing this tribute, I somehow feel Allen's presence as though I think he might be napping. I close with a quote from Thoreau: "The language of friendship is not words but meaning."

Allen, we miss you.

\section{From: Larissa Bresler, MD, DABMA}

Associate Professor of Urology, Obstetrics and Gynecology, Loyola University Medical Center and Hines VA

$\mathbf{T}$ He COMMUNities of the American Academy of Medical Acupuncture (AAMA) and Helms Medical Institute (HMI) mourn the passing of Allen McDaniels, MD, a co- founder of the AAMA; our dear friend, colleague, leader, and mentor.

During my acupuncture course I heard this distinguished gentleman with his signature mustache proclaim: "Do not be afraid of GV 1!" That was music to my urologic ears. I soon found out that this senior preceptor was Allen, the founding Secretary and Treasurer of the AAMA with more than 30 years of teaching experience. He earned my respect quickly due to his knowledge base, professional demeanor, and no-nonsense, "can do" attitude.

I found his teaching style to be patient and supportive at the same time as firm and methodical. As a friend and mentor, he radiated kindness and was known for his signature attire, facial hair, and a sense of humor. Allen had been in private medical practice in San Pedro, CA, for more than 36 years. His practice was devoted to medical acupuncture, preventive medicine, and health counseling.

He received his undergraduate and medical degrees from the University of Oregon and served a psychiatry/neurology residency at the Olive View/University of California Medical Center in Sylmar, CA. While Allen had been on the medical staffs of the Torrance Memorial Hospital and San Pedro Peninsula Hospital, he devoted most of his professional time to his private office practice and teaching.

Allen taught civilian and military acupuncture for more than 32 years and was a Senior Clinical Preceptor for the HMI, in Berkeley, CA

So long my friend, your spirit soars....

\section{From: Demetrios Papadopoulos, MD \\ Board Certified \\ American Board of Medical Acupuncture}

I

WOULD LIKE TO RECOGNIZE THE GREATNESS of Allen in his contributions to the practice and teachings of medical acupuncture. He touched my life significantly.

Allen was my preceptor during every session in the Helms Medical Institute (HMI) program. He was my practitioner when I volunteered to be a "patient" during the training. He taught me in the Board Certification preparation course. He taught me in every session for Chinese Scalp Acupuncture training. He was present during every one of my sessions as I participated as a para-preceptor in the HMI curriculum. I was further blessed to be able to interact with him during the American Academy of Medical Acupuncture symposia since 2016.

He was a magnificent teacher. He was a kind and perceptive healer. He had an amazing sense of humor.

He will be sorely missed by all of us in the acupuncture community. And, sadly, he will not be around to continue to promote and teach our art to more physicians in the future.

\section{From: Maya Myslenski, MD, DABMA}

Attending Physician, Department of Emergency Medicine Assistant Professor, Case Western Reserve University School of Medicine

MetroHealth Medical Center 
A LLEN WAS A DARLING, BELOVED FRIEND, a one-of-akind kindred spirit, and a great mentor. I'll be forever touched and grateful for his friendship. I'll always love him and miss him.

Allen was an amazing human being. He was knowledgeable and passionate about so many things. He loved to read and he loved to write. In fact, he devoted every Thursday to his writing. He was writing a historical novel and a "Water Book" about clean water. Last year he created a 90-minute video session in which he acted as a cameraman, sound man, set designer, and an interviewer of his old friend and colleague, a practicing mechanical engineer, about science and scientific method. Allen worked on this project for more than 40 years.

Allen loved nature. He said: " Nature is full of wonder." He loved observing it, reading about it, and painting it with watercolors. He was passionate about trees. He travelled to Sierra Nevada to plant thousands of trees to protect the forest. Allen drove there every year to check on his trees. He also enjoyed working on his garden and was so happy when his strawberries, beans, tomatoes, and artichokes were healthy and abundant. He had a special love for orchids. He traveled to the Santa Barbara (CA) Orchid Show and always brought home new flowers. At Christmas, he enjoyed the Christmas cacti. I got many, many flower photos from Allen. Some of the most spectacular were pictures of spring flowers blooming in the Southwest desert: orange poppies; purple lupins; and tiny yellow sunflowers.

Allen was excited about his new adventures. He started to learn fly fishing. He said "Ever since I saw the movie A River Runs Through It, I wanted to learn fly fishing. Fishing was a form of meditation for Allen. He started planning a trip to hike the Appalachian Trail. It was his dream.

Allen always talked affectionately about his family, mostly about his beloved wife, Phyllis, who had passed away few years ago. He missed her a lot. He also talked a lot about his three kitties: Penelope; Cally; and Orchid. He loved them dearly and missed them when he traveled. Allen traveled a lot to teach physician-acupuncture courses for the Helms Medical Institute and Acus Foundation. He loved to teach. He was a spectacular, caring, and inspirational teacher.

Allen was passionate about history, literature, and all the humanities. He really knew them. You could have a real indepth conversation with Allen on any subject, from current events and sports, to arts and philosophy, and, of course, medicine. He recommended so many books to me. Why Doctors Should Read Fiction: Could a Simple Literary Exercise Make Physicians More Caring? By Sam Kean. Or, Harvesting the Light: Using the Fruits of Spirit to Build a Spiritual Skill Set, by Robert Leichtman. And many more.

Allen had always been engaged in several projects at the same time. It was incredible to see how skilled he was, and how knowledgeable he was about so many subjects. From fixing a leak in a garage roof, to going on a genealogic adventure with his brother, and everything in between. Al- len was very humble. He thought that knowing a lot about everything was the most natural thing in the world. He said that planning his new projects and adventures kept him alert and alive and made his life interesting.

I called Allen on his birthday and said: "Don't change Allen. You are perfect". He replied "Not changing is alien to me. I'm always changing and adapting as life unfolds."

Allen was always available to answer any questions I had. And I had many. Acupuncture-related. Raising teenage boys-related. Life-related. I once asked him what his answer would be if a teenager asked him what the most important thing in life was. He said that there is an old song that answers that, "Nature Boy": "The most precious thing you'll ever learn is to love and be loved in return."

Some of Allen's favorite quotes that I'll always remember include:

"Take time to smell the roses."

"Disappointments happen for a reason, when a door closes, other doors open."

"Set aside 10-15 minutes daily by yourself without distraction to help your sanity and improve focus."

"When the going gets tough, the tough get going."

"Remember you can't care for others unless you care for yourself."

And a picture of a bottle of ketchup - a reminder to keep in touch. Allen had a great sense of humor. He told me he didn't take himself too seriously. He was down-to-earth, joyful, and full of life.

In his last e-mail, Allen sent me a poem written by John Keats "To Autumn" to remind me to slow down, stop worrying, and enjoy the beauty of the season. He was a generous and gracious master of making everyone feel welcome, appreciated, supported, and loved.

If he could, he would call each of us, who miss him, and he would say: "I'm with you, I'm thinking of you, I love you, and I'm sending you a bright and happy light to cheer you up.',

\section{From: Freda Dreher, MD}

Current President, American Academy of Medical Acupuncture (AAMA)

President, AAMA

Clinical Preceptor, Helms Medical Institute

Clinical Preceptor, Acus Foundation

Board-certified in physical medicine and rehabilitation

Board-certified in medical acupuncture

Private practice in Lebanon, $\mathrm{NH}$

A $S$ THE PRESIDENT of the American Academy of Medical Acupuncture (AAMA), I reported to the membership in November of 2019 that the AAMA had lost one of its founding fathers. Allen McDaniels, MD, who started his medical acupuncture practice in 1982, had passed away a few weeks prior. At a Helms Medical Institute (HMI) preceptor's training retreat the month before, he was fully engaged as Paul Unschuld lectured on the nuances of the $\mathrm{Nei}$ 
Jing, the complex history of China, and other factors we all consider as we practice the fine art of medical acupuncture. He appeared to be in full health and was loving life, actively learning all the days of his life.

Allen founded the AAMA along with Joseph M. Helms and John Reed. There were others involved in the inception of the organization but these 3 men were our true founders. They had a vision of what the AAMA could be, and they had the skills to implement the necessary actions to actualize their vision. The AAMA is their life's work realized. In particular, Allen was instrumental in fostering the AAMA's growth as well as contributing to Medical Acupuncture, leadership development, Continuing Medical Education accreditation, and the establishment of the Medical Acupuncture Research Foundation.

Allen completed Joe's acupuncture class in 1982 and his own meticulous student notebook evolved into the HMI course binder. He was part of the HMI preceptor team since 1984, urging, cajoling, pushing, and encouraging students along in his own unique way. He remained active in teaching and in his private practice until his passing.

I gained a full appreciation for Allen's skills when he offered me an acupuncture treatment for a recent injury. Being a physician, I knew what I needed. "Just put a couple of needles here and there and I'll be fine," was what I demanded. Allen would have no part of that. He gently and generously kept treating me. Auricular. Scalp. Local. Principal meridian subcircuit and electrical stimulation. I quietly wondered, "when's this guy going to quit?" He plodded along, making sure that he was the doctor and I was the patient. Not feeling a single needle insertion, I had a strong endorphin response and my body's healing response carried on. Allen was a master at the craft and humble in the clinic setting.

The AAMA and HMI have lost an esteemed senior leader. He brought a team approach to any group and, while providing leadership, was always willing to do whatever was asked of him. He modeled the compassionate healer and wise teacher.

We can all continue to learn from what Allen modeled. Be the very best acupuncturist you can be. Continue to learn from the classics. Keep current and fresh. Continue to show up, no matter how much the cards are stacked against it. Put the patient first when you're in the clinical setting. Be assertive and firm and gentle-all at the same time. Contribute to your professional organizations. Be a generous team player. Mentor others on their paths as healers. Nurture your outside interests and find joy in life. Remember your roots.

Allen was a good man. He will live on in our memories and through the legacy he created for us. 